Висновки. Отже, соціальна компетентність є однією з ключових компетентностей сучасної особистості, адже відповідає за ефективну життєдіяльність у суспільстві та конструктивну взаємодію з різними людьми, соціальними групами, інституціями. Структура соціальної компетентності передбачає низку компонентів, пов'язаних із соціальними знаннями, мотивацією, оцінкою соціальних ситуації, відповідною діяльністю та поведінкою. Соціальна компетентність студентів педагогічного університету є важливою складовою їхнього професійного становлення та передбачає у своїй структурі такі основні компоненти, як когнітивно-ціннісний, емоційно-мотиваційний, операційно-діяльнісний та рефлексивний.

Подальші наші наукові дослідження плануємо спрямувати на визначення критеріїв сформованості компонентів соціальної компетентності студентів педагогічних університетів.

\section{СПИСОК ВИКОРИСТАНОЇ ЛІТЕРАТУРИ}

1. Бекиров С. Н. Формирование компонентов социальной компетентности будущих педагогов в процессе их профессиональной подготовке в вузе. Проблемы современного педагогического образования. 2017. № 56-2. С. 16-22.

2. Борбич Н. Формування соціальної компетентності студентів педагогічних коледжів як соціально-педагогічна проблема. Проблеми підготовки сучасного вчителя. 2014. № 10 (1). С. 166-170.

3. Даценко Н. Про структуру соціальної компетентності учнів. Вісник Київського національного університету імені Тараса Шевченка. 2012. № 6. С. 8-10. (Серія «Психологія. Педагогіка. Соціальна робота»).

4. Докторович М. Соціальна компетентність як наукова проблема. Психологія $і$ суспільство. 2009. № 3 (37). C. 144-147.
5. Зарубінська I. Б. Проблема діагностики соціальної компетентності студентів вищих навчальних закладів. Інформаційні технологї $i$ засоби навчання. 2009. № 5 (13). URL: https://journal.iitta.gov.ua/ index.php/itlt/article/view/189/175 (дата звернення: 17.04.2020).

6. Качалова Т. Г. Структурно-функціональні компоненти дидактичної моделі формування соціальної компетентності студентів. Педагогіка вищої та середньої школи. 2014. № 43. С. 186-189.

7. Концепція «Нова українська школа». URL: https://www.kmu.gov.ua/storage/app/media/reforms/ ukrainska-shkola-compressed.pdf (дата звернення: 17.04.2020).

8. Москальова Л. Ю. Соціально-педагогічне проектування культурно-освітнього простору дітей та молоді в освітніх закладах: загальні положення. $\mathrm{Ha}$ уковий вісник Мелітопольського державного педагогічного університету. 2013. № 2. С. 187-190. (Серія «Педагогіка»).

9. Олексенко Р. І. Філософія розвитку інформаційного суспільства в епоху глобалізації. Гілея. 2015. № 38. C. 229-232.

10. Шаров С. В. Дефінітивний аналіз і сутність соціальної компетентності. Науковий часопис національного педагогічного університету імені М. П. Драгоманова. 2019. Серія 5 «Педагогічні науки: реалї та перспективи». Вип. 66. С. 200-203.

11. Шахрай В. М. Теоретико-методичні засади формування соціальної компетентності учнів основної і старшої школи засобами театрального мистецтва : автореф. дис. ... д-ра пед. наук : $13.00 .05 ; 13.00 .07$. Київ : Інститут проблем виховання НАПН України. 2016. 46 с.

Дата надходження до редакиіï: 25.05.2020 p.

Інна ШПИЧАК, кандидат педагогічних наук, стариий викладач кафедри педагогіки, психології та корекційної освіти Рівненського ОІППО

\title{
МОТИВАЦІЯ ПРОФЕСІЙНОГО ЗРОСТАННЯ ПЕДАГОГІВ В УМОВАХ НОВОЇ УКРАЇНСЬКОЇ ШКОЛИ
}

\footnotetext{
У статті висвітлено особливості формування мотивації педагогів до професійного зростання в умовах Нової украӥнської школи. Розкрито поняття «мотивачія» та «професійна мотивачія». Визначено умови, щзо сприяють мотивачї до професійного зростання вчителів в умовах змін та реформування освіти. Запропоновано діагностичні методики для визначення мотиваційної готовності педагогів до здійснення інновачійної діяльності.
}

Ключові слова: мотивація, професійне зростання, особистість педагога, Нова украӥнська школа.

В статье освещены особенности формирования мотивации педагогов к профессиональному росту в условиях Новой украинской школы. Раскрыто понятия «мотиваџия» и «профессиональная мотивация». Определень условия, способствующие мотиващии $\kappa$ профессиональному росту учителей в условиях 
изменений и реформирования образования. Предложено диагностические методики для определения мотивационной готовности педагогов к осуществлению инновачионной деятельности.

Ключевые слова: мотивация, профессиональный рост, личность педагога, Новая украинская школа.

The actuality of the topic revealed in the article is caused by the growing demand for quality education and upbringing, updating the forms and methods of organizing the educational process in educational institutions and the importance in this context of professional development of teachers. After all, a modern school needs a motivated teacher who aims for self-expression and self-realization.

The article highlights the peculiarities of the formation of teachers' motivation for professional growth in the New Ukrainian School. The concepts of «motivation» and "professional motivation» are revealed. It is determined that professional motivation includes a combination of motivations and internal conditions, motivational characteristics that determine, guide and regulate the process of improving professional competence and psychological readiness for innovation.

The influence of internal and external motivation of a teacher on his desire to develop professional competence is analyzed. Particular attention is paid to the internal incentives of professional self-improvement. The content of the teacher's professional growth is addressed.

The main motives of pedagogical activity are highlighted: ideals, professional interests, beliefs, social attitudes and professional values of the teacher.

The conditions that promote motivation for professional growth of teachers in the conditions of changes and reforming of education are characterized.

Diagnostic methods for determining their own mental state and motivational readiness of teachers to innovate (method "Teacher's ability for self-development», a questionnaire for teachers «Determination of the level of teaching staff members readiness to innovate») are proposed.

Based on the theoretical analysis of sources and literature, as well as the experience of training the teachers of the 1st grades of NUS, it is determined that the key roles in the professional reorientation of teachers are played by cognitive interest, intrinsic stimulus and desire to develop professionally significant qualities. Only on the basis of self-knowledge, identification of their strengths and weaknesses, as well as by clear vision of the purpose of their activities the teacher acquires the motivation for professional growth.

Key words: motivation, professional growth, teacher's personality, New Ukrainian School.

Постановка проблеми. Зміни, що відбуваються в сучасному глобалізованому світі, вплинули на всі сфери нашого життя. У контексті реформування освіти в Україні, реалізації Концепції «Нова українська школа» особлива увага звертається на педагога як рушія та агента змін. Сьогодення потребує висококваліфікованих фахівців, здатних швидко орієнтуватися в нових умовах, схильних до ризику, відкритих до нововведень та постійного розвитку.

Суперечності між стереотипами, що склалися, і запитами сьогоднішніх школярів змушують учителів задуматися про цілеспрямований розвиток професійної компетентності. Однією з базових, інтегрувальних складових діяльності педагога в умовах змін є мотивація професійного зростання, адже саме вона забезпечує постійний розвиток особистості відповідно до вимог професійної діяльності в ситуації соціальної, економічної, наукової, інформаційної невизначеності.

Аналіз наукових досліджень і публікацій. Питання мотивації професійної діяльності стало предметом дослідження багатьох науковців, зокрема значний внесок у вивчення проблеми мотивації праці зробили М. Вебер, А. Маслоу, А. Маршалл, А. Сміт, М. Кларін, О. Павловська, В. Семиченко, Л. Туріщева та ін. Особливості формування мотивації професійної діяльності педагога обгрунтовано в працях вітчизняних і зарубіжних дослідників: наприклад, психологічні чинники розвитку професійної кар'єри освітніх працівників розглядали Т. Зайчикова, Л. Карамушка, С. Максименко; мотивацію професійно-педагогічної спрямованості С. Занюк, С. Максименко, Н. Ничкало; формування мотивації педагогічної діяльності, розвиток педагогічної творчості - I. Зязюн, В. Моляко.

Проте проблема формування мотивації професійного зростання педагогів в умовах Нової української школи є досить актуальною і потребує більш детального висвітлення.

Мета статті - визначити основні особливості мотивації педагогів до професійного зростання в умовах Нової української школи.

Виклад основного матеріалу. Сучасні діти народилися в епоху швидких змін, вони живуть у час, коли необхідно вчитися впродовж життя. Тому школа має насамперед зберегти мотивацію до навчання, навчити дітей вчитися самостійно із задоволенням і без надмірних зусиль. Учні хочуть бачити вчителя талановитого, різнобічного, який буде партнером і водночас мудрим наставником.

Важливим стає новий ментальний підхід учителя до учнів, який включає такі аспекти: повага до особистості дитини; презумпція талановитості дитини; підтримка їі життєвого оптимізму; радість пізнання; розвиток самостійності, незалежного мислення, креативності дитини, іiі самоповаги та впевненості в собі; взаємодія на основі партнерства; створення атмосфери довіри і взаємоповаги.

Щоб реалізувати ці завдання сучасному педагогові необхідні гнучкість і нестандартність мислення, уміння адаптуватися до швидких змін та умов життя. А це можливо лише за наявності високого рівня професійної компетентності, розвинених професійних здібностей. Сьогодні школі потрібен умотивований учитель, який прагне до самовираження та самореалізації.

Водночас серед педагогічної спільноти спостерігається криза мотивації і неоднозначне сприйняття нового. Зміни завдань сучасної освіти зумовлюють певні суперечності, які стимулюють або стримують педагогів у прагненні до підвищення професійної компетентності. Зазначені суперечності можна поділити на декілька груп:

- периа - суперечності між рівнем соціального забезпечення вчителя та професійними аспектами його діяльності;

- друга - суперечності суб'єкта діяльності, які пов'язані з невідповідністю між соціально-освітньою ситуацією, яка швидко змінюється, і стилем діяльності педагога, який уже склався впродовж років;

- третя - суперечності між творчою спрямованістю педагога й існуючими педагогічними канонами, нормативами, притаманними педагогічному колективу, органам управління, батькам. 
На основі ставлення до змін та нововведень К. Роджерс виокремив п'ять категорій учителів:

1) новатори - учителі, які завжди першими сприймають усе нове, сміливо його впроваджують і поширюють;

2) учителі, які першими здійснюють практичну (експериментальну) перевірку цінностей інновацій у кожній школі;

3) помірковані вчителі, які дотримуються правила «золотої середини» і не сприймають нового до того часу, поки його не впровадять більшість колег;

4) учителі, які більше сумніваються, ніж вірять у нове; вони більш орієнтовані на старі технології, ніж на нові, сприймають нове лише за умови загальної позитивної громадської думки;

5) педагоги, в яких дуже сильний зв'язок із традиційним, старим підходом до навчання і виховання, вони консервативні та відкидають усе нове [9].

Під час тренінгів для вчителів 1-х класів НУШ спостерігаємо, що ключову роль у професійній переорієнтації педагогів відіграє внутрішній стимул та бажання розвивати професійно значущі якості.

Лише через розуміння мотивів діяльності педагога можна ефективно організувати процес підвищення його професійної компетентності. Адже розуміючи, що рухає людину, що стимулює їі, які мотиви покладено в основу іiї дій, можна створити ефективну систему професійного зростання.

Поняття «мотивація» у психології має декілька трактувань: це - наявність певної системи факторів, сукупність причин, які спонукають до активності; свідоме використання системи мотивів, які сприяють активізації певних дій; процес розгортання певної системи мотиваторів у структурі відповідної діяльності [10, с. 37].

На думку вітчизняних та зарубіжних учених (А. Божович, В. Гладкова, І. Підласий та ін.), мотивація є рушійною силою людської діяльності для досягнення конкретної мети, зокрема в освітній сфері для забезпечення ii якості. Мотивація відіграє провідну роль у формуванні професійної поведінки та діяльності педагогів [7].

Мотив - це те, що спонукає людину до дії. Мотивом завжди $є$ переживання чогось особистісно значущого для людини. Не усвідомлюючи мотивів, не можна зрозуміти, чому особа прагне до цієї, а не до іншої мети, тому не можна зрозуміти істинного сенсу iï діяльності [2, с. 49]

Таким чином, можна підсумувати: мотив - це складова мотиваційної сфери людини. Він спрямований на задоволення потреби особистості, спонукає іiі до дії, є особистісно значущим для неї. Поняття «мотивація» С. Занюк трактує як сукупність спонукальних факторів, що визначають активність особистості; це всі мотиви, потреби, стимули, ситуативні чинники, які спонукають поведінку людини [1].

Мотив педагогічної діяльності - це внутрішній рушій, що спонукає педагога до професійної діяльності. Мотивами можуть бути ідеали, професійні інтереси, переконання, соціальні установки та професійні цінності педагога. Проте в основу формування мотиву покладено насамперед потреби. Під мотиваційною сферою особистості розуміють стійкі мотиви, що мають певну ієрархію і визначаються у спрямованості особистості.
Дослідження мотивації педагога показало, що вона складається із зовнішніх та внутрішніх мотивів.

Внутрішня мотивація пов'язана зі змістом педагогічної діяльності і грунтується на потребі у спілкуванні $з$ учнями. Зовнішня мотивація зумовлена чинниками, які не мають безпосереднього зв'язку 3 професійною діяльністю. Внутрішньо мотивована поведінка здійснюється заради себе самої (сам процес і зміст діяльності викликає інтерес). Тоді як зовнішній мотив актуалізується, коли головною причиною діяльності $є$ отримання того, що перебуває поза нею (грошей, слави, влади тощо). Зазвичай кожна діяльність завжди спонукається комплексом, поєднанням внутрішніх і зовнішніх мотивів [1, с. 120].

На думку Л. Омельченко, розвиток внутрішньої мотивації педагогічної діяльності зумовлюють переживання особистістю власної автономії й особистісної причинності, відчуття себе джерелом змін в освітньому процесі. Ще один фактор - відчуття власної компетентності, власних можливостей - теж $є$ важливою спонукою педагогічної діяльності й характеризує її внутрішню мотивацію [6, с. 129].

Розглянемо зміст професійного зростання вчителя для визначення тих умов, які б сприяли розвитку його мотивації.

Професійне зростання педагога пов'язане з набуттям нових компетенцій, знань, умінь і навиків, які він використовує чи буде використовувати у своїй професійній діяльності з метою надання якісної освіти.

Таким чином, професійне зростання - це свідомий, цілеспрямований процес підвищення рівня своєї професійної компетентності та розвитку професійних якостей відповідно до зовнішніх соціальних вимог, умов професійної діяльності та особистої програми розвитку.

Варто зауважити, що професійний розвиток $є$ одним з елементів особистого розвитку людини. Усвідомлення педагогом своїх сильних сторін та потенційних можливостей спонукають його до експериментування, творчої реалізації. Важливим елементом професійного зростання педагога є свобода вибору, а також відчуття своєї відповідальності за все, що відбувається.

Зважаючи на викладене вище, мотивація діяльності педагога зумовлена його професійними інтересами, ціннісними орієнтаціями, ідеалами. Вона виявляється як у всій його професійній життєдіяльності, так i в окремих педагогічних ситуаціях, визначає його сприйняття зовнішніх подій і логіку поведінки.

До ідеї необхідності змін та інновацій багато вчителів приходять через невдоволеність власною професійною діяльністю у межах традиційного педагогічного процесу.

Успіх нововведень багато в чому визначається здатністю педагогів до інноваційної, творчої, пошукової діяльності. Особливе значення тут належить розвитку мотивації професійного зростання, яка включає сукупність спонукань і внутрішніх умов, мотиваційних характеристик, які детермінують, спрямовують i регулюють процес підвищення професійної компетентності та психологічної готовності до інноваційної діяльності.

Психологічну готовність педагога до інноваційної педагогічної діяльності можна визначити як особистісний стан мотиваційно-ціннісного ставлення до професійної діяльності, володіння ефективними способами і засобами досягнення педагогічних цілей, 
здатності до творчості та рефлексії. Структуру готовності до інноваційної педагогічної діяльності розглядають як сукупність мотиваційного, когнітивного, креативного, рефлексивного компонентів, які пов'язані між собою.

Задля того, аби вчитель зміг ефективно реалізовувати нові функції і професійні ролі в новій школі, впроваджувати нові освітні технології, він повинен насамперед володіти інформацією щодо власного психічного стану та мотиваційної готовності до здійснення інноваційної діяльності. Тому пропонуємо для розгляду такі діагностичні методики.

I. Методика «Здатність педагога до саморозвитку» Фах

Стаж роботи

Інструкиія. Оцініть, наскільки вказані нижче твердження збігаються зі звичним для Вас способом дій, позначивши відповідні бали:

5 - дане твердження повністю відповідає дійсності;

4 - швидше відповідає, ніж ні;

3 - і так, і ні;

2 - швидше не відповідає;

1 - зовсім не відповідає.

Таблиияя

\begin{tabular}{|c|l|c|}
\hline $\begin{array}{c}\text { № } \\
\text { 3/п }\end{array}$ & \multicolumn{1}{|c|}{ Твердження } & Бали \\
\hline 1 & Я прагну вивчити себе & 12345 \\
\hline 2 & Я залишаю час для розвитку, яким би не був зайнятим роботою й хатніми справами & 12345 \\
\hline 3 & Перешкоди, що виникають, стимулюють мою активність & 12345 \\
\hline 4 & Я шукаю зворотний зв’язок, оскільки це допомагає мені пізнати й оцінити себе & 12345 \\
\hline 5 & Я рефлексую свою діяльність, знаходячи для цього спеціальний час & 12345 \\
\hline 6 & Я аналізую свої почуття й досвід & 12345 \\
\hline 7 & Я багато читаю & 12345 \\
\hline 8 & Я широко дискутую з приводу тих питань, які мене цікавлять & 12345 \\
\hline 9 & Я вірю у власні можливості & 12345 \\
\hline 10 & Я прагну бути більш відкритим & 12345 \\
\hline 11 & Я усвідомлюю той вплив, який здійснюють на мене оточуючі люди & 12345 \\
\hline 12 & Я керую своїм професійним розвитком й отримую позитивні результати & 12345 \\
\hline 13 & Я отримую задоволення від засвоєння нового & 12345 \\
\hline 14 & Зростаюча відповідальність мене не лякає & 12345 \\
\hline 15 & Я позитивно поставився (-лася) б до мого кар'єрного росту & 12345 \\
\hline
\end{tabular}

Опрацювання та інтерпретація результатів Знайти суму балів:

- 60-75 балів - високий рівень саморозвитку, готовність до змін і нововведень;

- 45-60 балів - достатній рівень саморозвитку, готовність активно використовувати окремі інновації;

- 15-45 балів - недостатній рівень саморозвитку, бажання уникнути змін та нововведень.

\section{II. Визначення рівня готовності членів педагогічних колективів до інноваційної діяльності}

\section{АНКЕТА ДЛЯ ВЧИТЕЛЯ}

1. Чи завжди Вам цікаві новації та експерименти в педагогічній діяльності?

- так;

- $\mathrm{Hi}$;

- не впевнена (-ний).

2. Скільки разів Ви пробували застосовувати нововведення у своїй роботі?

- неодноразово;

- декілька разів;

- жодного разу.

3. Які, на Вашу думку, основні причини, щио гальмують упроваджсенн нових педагогічних ідей $i$ технологій (вкажіть не більще ніж три варіанти відповідей):

- недостатнє матеріальне забезпечення;

- надмірна насиченість матеріалу;

• психологічна неготовність учнів до сприйняття інновацій;

- поспішне впровадження;

• консерватизм в освіті;
• погане володіння комп’ютером;

- нестача часу;

- недостатне знання психології дитини.

4. Якими ознаками готовності до інновацій Ви володієте?

- прагнення пізнати нове;

- бажання експериментувати;

- креативність;

- попередній досвід.

5. Чим для Вас приваблива інноваційна діяльність? Виберіть одну відповідь:

- розвиває інтерес учнів до вивчення предмета;

- дає можливість учителю проявити власний потенціал;

- удосконалює педагогічну майстерність учителя;

- дає можливість запроваджувати нові методи і форми роботи з дітьми;

- бажання дізнатися щось нове;

- інше

6. Які освітні технології Ви могли б застосовувати за сприятливих умов? Виберіть не більше двох варіантів відповідей:

- проєктні технології;

- особистісно орієнтоване навчання;

- інтегроване навчання;

- випереджувальне навчання;

- інше

7. Якими діагностичними методами Ви володієте вільно? Виберіть всі можсливі варіанти відповідей:

- опитування;

- бесіда;

- анкетування;

- спостереження; 
- інтерв'ювання;

- вивчення стану проблеми;

- аналіз документів;

- аналіз досвіду роботи вчителя;

- кількісне обробляння результатів дослідження;

• педагогічний експеримент;

-інше

8. Оберіть основну причину несприйняття інноваційних процесів? Виберіть не більще ніж чотири варіанти відповіді:

- не знаю, які будуть наслідки змін;

- не хочу змінювати власний стиль викладання;

- будь-які нововведення не так сприятимуть вирішенню проблем, як примножать їхнє число;

- упровадження інновацій суттєво впливає на інтенсифікацію праці, зростання навантаження на вчителя;

• не вважаю за доцільне витрачати час на перенавчання;

- мені ніколи цим займатися;

- вважаю будь-які нововведення тимчасовим, швидкоплинним явищем;

- уважаю будь-які нововведення даниною моді, а не дієвим засобом перетворення;

- не можу зорієнтуватися в інформаційному потоці: не знаю, із чого почати;

- інші причини

9. Де Ви останнім часом отримували інформацію про освітні інновації?

- на курсах підвищення кваліфікації;

- на районних семінарах;

- на засіданнях педагогічної ради школи;

• на засіданні шкільного методичного об'єднання;

- із педагогічної преси, Інтернету;

•інше

10. Що Ви вважаєте основною складовою успіху?

- упевненість у собі;

- чітке бачення мети;

- самостійно поставлена мета, наполегливість;

- пошук і внесення новизни.

11. Як називається Нова українська школа в контексті нового Закону Украӥни «Про освіту»?

- школа розвитку та перспектив;

- школа особистісно зорієнтованого навчання;

- школа компетентностей XXI століття;

• школа радості;

- школа майбутнього.

12. Які вміння та навички будуть найбільш потрібні роботодавцям у 2020 році (за результатами роботи Світового економічного форуму у 2016 році)? Оберіть три правильні відповіді:

- точність та пунктуальність;

- емоційний інтелект;

• виконавська дисципліна;

- креативність;

- критичне мислення.

13. Укажіть, яке слово пропущене в реченні.

На відміну від знаннєвої школи компетентнісна має дати дитині не лише знання, а й сучасні вміння та навички. А також формувати ставлення в різних ситуаціях.

14. Оберіть три правильні твердження щцодо плану впровадження реформ в освіті:

- усі етапи навчання стартують одночасно;

- базова школа стартує 01.09.2022;
• старша профільна школа стартує 01.09.2027;

- планом ще не визначено старт реформ;

• початкова школа стартує 01.09.2018.

15. Обов'язкові результати навчання в Державному стандарті початкової освіти сформульовано через:

- розвиток компетентностей, умінь і досвіду кожної дитини;

- окреслене ядро знань, яке має засвоїти учень/ учениця;

- перелік тем, які має подати вчитель.

Таким чином, проходження запропонованих діагностичних методик у сукупності 3 іншими дасть можливість визначити ставлення педагога до своєї професійної діяльності, ставлення до себе як професіонала, готовність до роботи в умовах змін та інновацій. На основі самопізнання, визначення своїх сильних і слабких сторін у вчителя 3'являється бажання займатися самовдосконаленням та створюється своєрідна модель роботи над собою.

Висновки. Отже, нами було 3'ясовано, що мотивація педагогів відіграє ключову роль у підвищенні їхньої професійної компетентності та зростання. Лише вмотивований педагог, готовий до змін та самовдосконалення, буде адекватно реагувати на виклики сучасного світу, вирішувати основні проблеми освіти та виховання підростаючих поколінь, упроваджувати нові освітні технології. Мотивація педагогів до професійного зростання в умовах Нової української школи зумовлена їхніми професійними інтересами, ціннісними орієнтаціями, ідеалами, психологічною готовністю до змін та інновацій.

\section{СПИСОК ВИКОРИСТАНОЇ ЛІТЕРАТУРИ}

1. Занюк С. С. Психологія мотивації : навч. посібник. Київ : Либідь, 2002. 304 с.

2. Леонтьев А. Н. Деятельность, сознание, личность. Москва : Политиздат, 1977. 304 с.

3. Мазяр О. В., Кириченко В. В. Психологія праці: модульний курс : навч. посібник. Житомир : видво ЖДУ ім. І. Франка, 2014. 190 с.

4. Нова українська школа. Концептуальні засади реформування середньої школи. URL: https:// www.kmu.gov.ua/storage/app/media/reforms/ukrainskashkola-compressed.pdf (дата звернення: 15.04.2020).

5. Нова українська школа: порадник для вчителя / за заг. ред. Н. М. Бібік. Київ : ТОВ «Вид. дім «Плеяди»», 2017. $206 \mathrm{c}$.

6. Омельченко Л. М. Внутрішня мотивація педагогічної діяльності: сутність та чинники. Наука і освіma. 2014. № 7. C. 128-130.

7. Підласий І. П. Продуктивний педагог. Настільна книга вчителя. Харків : Вид. група «Основа», 2010. $360 \mathrm{c}$.

8. Психологу для роботи. Діагностичні методики : збірник / [уклад. : М. В. Лемак, В. Ю. Петрище]. Вид. 2-ге, виправл. Ужгород : Видавництво Олександра Гаркуші, 2011. 616 с.

9. Роджерс К. Р. Особисті роздуми щодо викладання і навчання. Відкрита освіта. 1993. № 5. С. 22-24.

10. Семиченко В. А. Проблемы мотивации поведения и деятельности человека. Модульный курс психологии. Киев : Миллениум, 2004. 521 с.

Дата надходження до редакиії: 15.06.2020 p. 